Економічні науки: збірник наукових праџь Луцького національного технічного університету. - Серія "Регіональна економіка". - Випуск 16 (63). - Редкол.: відп. ред. д.е.н., професор Л.Л. Ковальська - Луцьк : ІВВ Луцького НТУ, 2019. -173 с.

УДК 330.142

Потьомкіна О.В., к.е.н., доцент

Шульган Ж.А.

Луцький національний технічний університет

\title{
СУЧАСНИЙ СТАН ТА НАПРЯМИ ВДОСКОНАЛЕННЯ СИСТЕМИ ПРАЦЕВЛАШТУВАННЯ У ВОЛИНСЬКІЙ ОБЛАСТІ
}

У статті проведено аналіз організації системи працевлаштування у Волинській області. Охарактеризовано тенденції розвитку та основні чинники, що впливають на рівень працевлаштування. Визначено напрями вдосконалення системи працевлаштування у регіоні

Ключові слова: працевлаштування, ринок праці, трудові ресурси.

Potomkina E., Shulgan Zh.

\section{THE CURRENT STATE AND DIRECTIONS OF IMPROVEMENT OF THE EMPLOYMENT SYSTEM IN VOLYN REGION}

In the article describes the current state of the employment system in the Volyn region. The research shows that today such tendencies as increasing employment problems, decreasing competitiveness of labor potential, result in the fact that the number of unemployed is increasing.

There is a need to develop new employment programs to ensure effective organization of employment in the system of socio-economic and legal measures.

Problems of organization and efficiency of employment are considered in scientific works of Ukrainian and foreign scientists such as Babaskin A., Bolotina N., Begichev B., Kiselev I., Lushnikov M, Pilipenko P., Venediktov V., Tolkunova V., Khutoryan N., Chanisheva G., Yaroshenko O., Jackman R.,. Leard R., Parsons T., Stanley G, Filer R. and others.

However, there are a number of issues that require further research. This concerns the study of the effectiveness of the organization of employment and development forecasting.

The research considers necessity to use a set of indicators that characterize employment, in particular: the economically active and inactive population, employment, unemployment, the load of unemployed in the workplace, the demand and supply of labor, the number of vacancies and employed persons for the study period.

The organization of the employment system in the Volyn region indicates that the long-term imperfection of interaction between the labor market and 
Економічні науки: збірник наукових праиь Луиького національного технічного університету. - Серія "Регіональна економіка". - Випуск 16 (63). - Редкол.: відп. ред. д.е.н., професор Л.Л. Ковальська - Луцьк : ІВВ Луиького НТУ, 2019. - 173 с.

education subjects negatively affected the employment system and the labor market, causing inconsistency of professional and qualification standards with the requirements of production, worsening the quality of training and imbalances professions. The purpose of interaction between the labor market and education actors is to maximize the satisfaction of all stakeholders, which on the one hand balances the demand and supply for skilled labor, to achieve higher quality of education (improving its content and improving its form), and on the other - to satisfy all in relevant educational products and (services).

The most promising tools for regulating the level of employment are those that take into account the impact of global trends and are aimed at enhancing innovation employment, entrepreneurial activity of the population, ensuring the balance of the educational services and labor market, forecasting the volume and structure of supply and demand for, improving the competitiveness of employees places.

Therefore, the article determines that the main directions of increasing the efficiency of employment are the collection and dissemination of information on the state of demand and supply in the labor market; a holistic system of professional education for the unemployed or those at risk of unemployment; professional education and retraining programs to increase the competitiveness of the unemployed market; development of regional employment programs and targeted community service programs; development of social security system. Foreign experience in organizing public works makes it possible to use the labor force more rationally, to create temporary employment for the unemployed population both at the regional level and during the implementation of national projects.

Key words: employment, labor market, labor resources.

Потёмкина А.В., Шульган Ж.А.

\section{СОВРЕМЕННОЕ СОСТОЯНИЕ И НАПРАВЛЕНИЯ СОВЕРШЕНСТВОВАНИЯ СИСТЕМЫ ТРУДОУСТРОЙСТВО В ВОЛЫНСКОЙ ОБЛАСТИ}

В статье проведен анализ организации системы трудоустройства в Волынской области. Охарактеризованы тенденции развития и основные факторы, влияющие на уровень трудоустройства. Определены направления совершенствования системы трудоустройства в регионе

Ключевые слова: трудоустройство, рынок труда, трудовые ресурсы.

Постановка проблеми у загальному вигляді та її зв'язок із важливими науковими i практичними завданнями. Сучасний стан ринку праці в Україні характеризується збільшенням проблем у сфері 
Економічні науки: збірник наукових праџь Луцького національного технічного університету. - Серія "Регіональна економіка". - Випуск 16 (63). - Редкол.: відп. ред. д.е.н., професор Л.Л. Ковальська - Луцьк : ІВВ Луцького НТУ, 2019. -173 с.

працевлаштування, що проявляється у зниженні конкурентоспроможності працівників i, як наслідок - зростання чисельності безробітних. Не дивлячись на те, що на сьогодні у світі спостерігається тенденція передачі машинам i комп'ютерам фізичних та навіть певних інтелектуальних функцій працівника, значення людської праці зростає. Виходячи з цього, виникає необхідність у розробці нових програм зайнятості населення для забезпечення ефективної організації працевлаштування трудових ресурсів в системі соціально-економічних і організаційно-правових заходів [1].

Аналіз останніх досліджень і публікацій, в яких започатковано розв'язання даної проблеми. Проблеми організації та ефективності працевлаштування розглянуті у наукових працях українських та закордонних вчених різних галузевих наук, серед яких А.Ю.Бабаскін, Н.Б. Болотіна, Б.К. Бегічев, І.Я. Кисельов, М.В. Лушнікова, П.Д. Пилипенко, В.С. Венедіктов, В.М. Толкунова, Н.М. Хуторян, Г.І. Чанишева, О.М. Ярошенко, Р. Джекман, Р. Леярд, Т. Парсонс, Г. Стенлі, Р. Філер тощо [1].

Проте, залишається ряд питань, що потребують додаткових досліджень, зокрема, це стосується дослідження ефективності організації системи працевлаштування та прогнозування розвитку, що обумовлює вибір теми та актуальність дослідження.

Цілі статті. Метою статті $є$ дослідження організації працевлаштування населення у Волинській області для визначення напрямів вдосконалення системи працевлаштування та збільшення іiі ефективності.

Виклад основного матеріалу дослідження 3 повним обгрунтуванням отриманих наукових результатів. Для обгрунтування удосконалення системи працевлаштування було проаналізовано сукупність показників, що характеризують стан працевлаштування, зокрема: економічно активне та неактивне населення, попит та пропозицію на робочу силу, кількість вільних вакансій та працевлаштованих осіб за досліджуваний період [2; 3]. 
Економічні науки: збірник наукових праџь Луцького національного технічного університету. - Серія "Регіональна економіка". - Випуск 16 (63). - Редкол.: відп. ред. д.е.н., професор Л.Л. Ковальська - Луцьк : ІВВ Луцьького НТУ, 2019. -173 с.

Для дослідження було використано статистичну інформацію [2;3;4], яка показала наступні результати: динаміка економічно активного населення у віці 15-70 років впродовж 2014-2018 рр. мала тенденцію до постійного зниження, проте незначне підвищення економічно активного населення працездатного віку відбулось у 2018 році. Скорочення пояснюється загальним зниженням кількості населення, що викликано перевищенням показника смертності над показником народжуваності, старінням нації, зовнішніми міграціями українців тощо. Така ситуація регіонального ринку праці, яка характеризується демографічною кризою, потребує особливої уваги, зокрема, дефіцит трудових ресурсів негативно впливає на соціально-економічну безпеку регіону, здійснює вплив на обсяги валового внутрішнього продукту.

Наступний етап - аналіз попиту та пропозиції на ринку праці Волинської області (Рис.1).

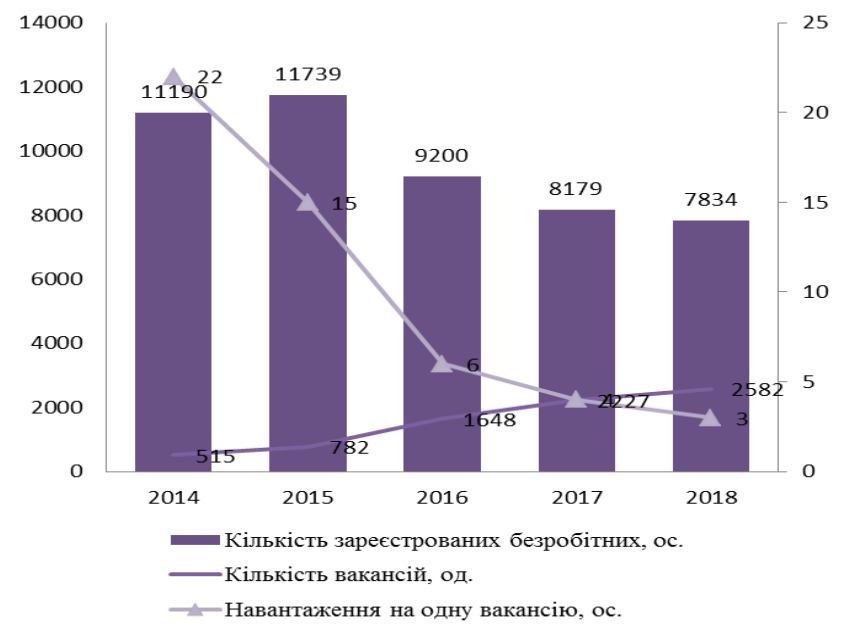

Рис. 1. Попит та пропозиція робочої сили у Волинській області у 2014-2018 pp. (складено на основі літературних джерел [2;3])

3 рисунку видно, що попит на працю значно перевищує пропозицію, виражену у кількості вакансій, протягом 
Економічні науки: збірник наукових праџь Луцького національного технічного університету. - Серія "Регіональна економіка". - Випуск 16 (63). - Редкол.: відп. ред. д.е.н., професор Л.Л. Ковальська - Луцьк : ІВВ Луцьького НТУ, 2019. - 173 с.

2014-2018 pр. В той же час кількість зареєстрованих безробітних 3 кожним роком зменшується, а пропозиція має позитивну тенденцію. У 2014 році на 11190 безробітних припадало 515 вакансій на заміщення робочих місць, тоді як у 2018 році на 7834 особи припало 2582 вакансії. Відповідно, кількість безробітних в області зменшилась на 3356 осіб, а пропозиція праці зросла на 2067 одиниць вакансій.

Вивчаючи статистику безробіття розуміємо, що явище має значення більше для розуміння того, які трудові ресурси сьогодні можуть бути використані в економіці регіону. Динаміка збільшення кількості безробітних також може сигналізувати про проблеми на ринку праці.

Бачимо, що кількість безробітних в області протягом досліджуваних років коливається. Центри зайнятості пропонують вакансії на вибір, але безробітних відлякує зарплата, яка подекуди не становить мінімальну заробітну плату. Оскільки, орієнтація підприємств на оптимізацію видатків 3 одного боку підвищує вимоги до компетентності персоналу, з іншого - не призводить до підвищення заробітної плати [5; 6].

Для Волинської області характерним $є$ значна частка зайнятих у промисловості, торгівлі і сільському господарстві. Така специфічна структура зайнятості зумовлена економікогеографічним (прикордонним) положенням території, що сприяє розвитку торгівлі, а також традицією ведення сільського господарства. Висока частка зайнятих у промисловості пояснюється наявністю промислових об'єктів (харчової, переробної, видобувної промисловості та машинобудування), які розміщені здебільшого у великих містах області.

Динаміка попиту та пропозиції робочої сили на ринку праці області характеризується перевищенням пропозиції робочої сили над іiі попитом, а також тенденціями до росту у цілому по області попиту на робочу силу та скорочення іiі пропозиції. У переважній більшості адміністративних районів області можна виділити такі, де помітна тенденція до скорочення пропозиції робочої сили. 
Економічні науки: збірник наукових праџь Луцького національного технічного університету. - Серія "Регіональна економіка". - Випуск 16 (63). - Редкол.: відп. ред. д.е.н., професор Л.Л. Ковальська - Луцьк : ІВВ Луцьккого НТУ, 2019. -173 с.

Лише Луцький район характеризується певним ростом пропозиції робочої сили. Це пояснюється близькістю до обласного центру, а відповідно кращими можливостями працевлаштування. Тому серед інших адміністративних районів відбувається скорочення пропозиції зареєстрованої робочої сили, оскільки тривалість очікування працевлаштування та рівень оплати праці, яку пропонує державна служба зайнятості, часто не відповідає потребам, особливо молодого, працездатного населення, яке працевлаштовується неофіційно та на короткостроковий період.

Що стосується попиту на робочу силу у 2014 році, то такі райони, як Ковельський, Володимир-Волинський, Горохівський, Ківерцівський, та Луцький та м. Луцьк, м. Ковель, м. Нововолинськ, м. Володимир-Волинський характеризуються тенденцією до його росту. Переважно це зумовлено наявністю об'єктів виробництва, а відповідно і потребами заповнення вакантних місць.

На кінець 2018 року, різниця пропозиції праці між областями дещо зрівнялась, хоча найбільші показники залишились у м.Луцьку та районі, значно збільшилась у м. Ковелі а районі, м.Нововолинську, Горохівському та Ківерцівському районах.

Як результат співвідношення попиту та пропозиції робочої сили $є$ показники навантаження на одне вільне робоче місце (вакансію). Для адміністративних районів і міст області навантаження на одне вільне робоче місце (вакансію) у 2014 році складало у середньому 22 особи, у 2018 році - 3. До районів з найвищими показниками за весь досліджуваний період належать Любомльський, Шацький, Рожищенський, Ківерцівський; 3 найнижчими - Камінь-Каширський, м. Нововолинськ i м. Луцьк. Щодо динаміки, то помітне зменшення навантаження у цілому по області, крім Рожищенського та Ківерцівського районів, де за досліджувані роки навантаження на одне робоче місце значно збільшилось.

Отже, у 2014-2015 році найбільш негативними чинниками впливу на розвиток ситуації 3 працевлаштування стали 
Економічні науки: збірник наукових праиь Луиького національного технічного університету. - Серія "Регіональна економіка". - Випуск 16 (63). - Редкол.: відп. ред. д.е.н., професор Л.Л. Ковальська - Луцьк : ІВВ Луцького НТУ, 2019. -173 с.

загострення військово-політичної ситуації на сході України, загальна макроекономічна нестабільність та суттєва девальвація національної валюти.

Основні скорочення робочої сили у 2014-2015 роках вже відбулись і найбільш поширеною тактикою підприємств регіону було вичікування, наслідком чого спостерігаємо скорочення кількості вакансій. Орієнтація підприємств на оптимізацію штатів призвела до незначного скорочення загальної кількості робочих місць, але таке скорочення фактично не загрожувало працівникам робітничих професій. Основними проблемними питаннями у 2014-2015 рр. були високе навантаження незайнятих громадян на одне вільне робоче місце (вакантну посаду), станом на 01.01.2014 р. цей показник у цілому по області склав 22 особи, тоді як станом на 01.01.1018 р. - 5 осіб $[2 ; 3 ; 6]$.

Наступний блок дослідження - динаміка працевлаштування населення у Волинській області у розрізі районів та великих міст області (Рис. 2).

3 рисунку видно, що кількість працевлаштованих осіб протягом останніх років зменшується в цілому по області та у розрізі регіонів.

Найбільш перспективними інструментами регулювання рівня працевлаштування $\epsilon$ ті, що враховують вплив глобальних трендів і спрямовані на активізацію інноваційної зайнятості, підприємницької діяльності населення, забезпечення збалансованості ринку освітніх послуг та ринку праці, прогнозування обсягу i структури попиту i пропозиції на, підвищення конкурентоспроможності фахівців і розширення кола робочих місць.

Під час дослідження організації системи працевлаштування у Волинській області ми зробили висновок, що довготривала недосконалість взаємодії суб'єктів ринків праці та освіти негативно відображалася на обох ринках, зумовлюючи невідповідність професійно-кваліфікаційних стандартів вимогам виробництва, погіршуючи якість підготовки кадрів та загострюючи дисбаланс вакансій за професіями. 
Економічні науки: збірник наукових праџь Луцького національного технічного університету. - Серія "Регіональна економіка". - Випуск 16 (63). - Редкол.: відп. ред. д.е.н., професор Л.Л. Ковальська - Луцьк : ІВВ Луцького НТУ, 2019. -173 с.

Метою взаємодії суб'єктів ринків праці та освіти є максимальне задоволення потреб всіх зацікавлених сторін, що з одного боку дозволяє збалансувати попит та пропозицію на кваліфіковану робочу силу, досягти вищої якості освіти (покращення іï змісту та удосконалення форми), а $з$ іншого - задовольнити всіх у відповідних освітніх продуктах та (послугах).

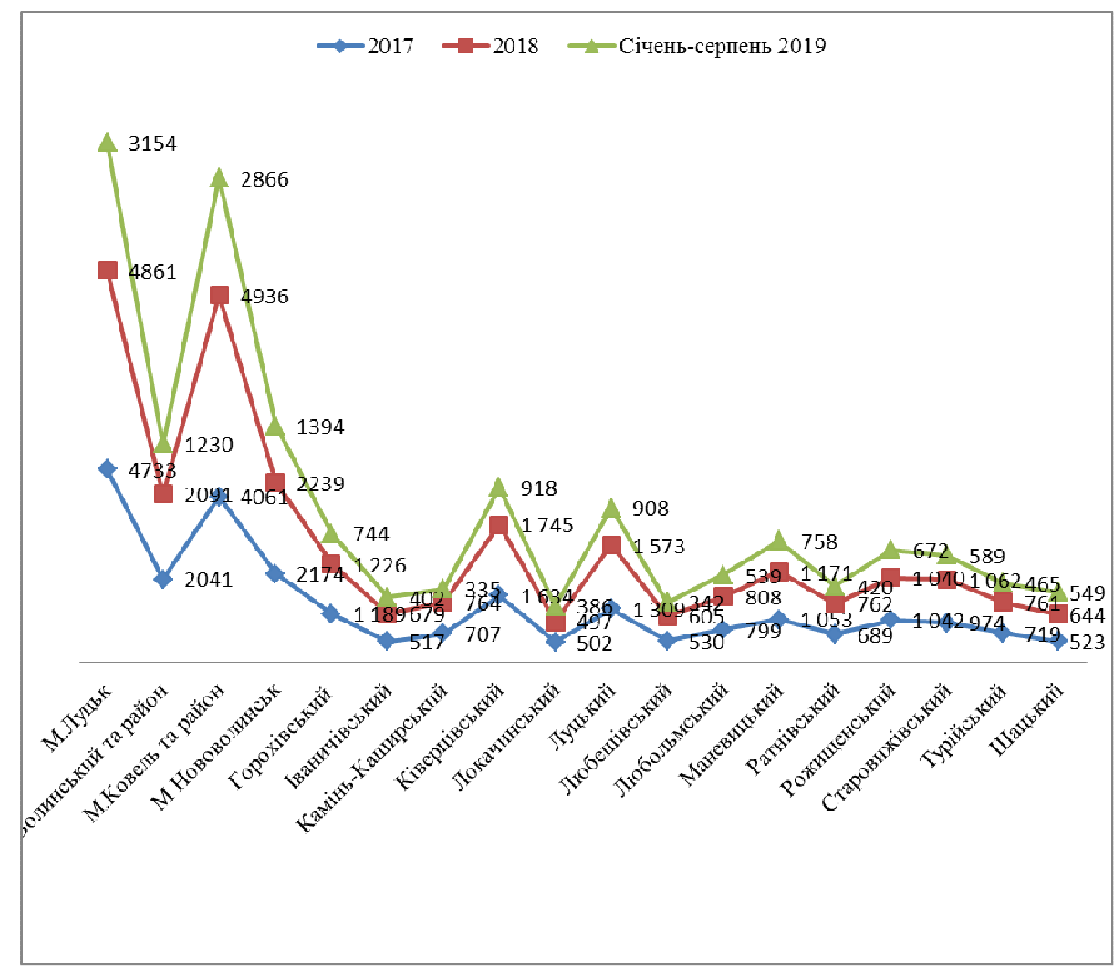

Рис. 2. Всього працевлаштовано, осіб (у т.ч. до набуття статусу безробітного) (складено на основі літературних джерел [2;3])

Висновки. Отже, дослідивши сучасний стан системи працевлаштування у Волинській області було визначено, що основними напрямами підвищення ефективності працевлаштування ефективності $€$ збір та розповсюдження 
Економічні науки: збірник наукових праџь Луцького національного технічного університету. - Серія "Регіональна економіка". - Випуск 16 (63). - Редкол.: відп. ред. д.е.н., професор Л.Л. Ковальська - Луцьк : ІВВ Луиького НТУ, 2019. - 173 с.

інформації щодо стану попиту і пропозиції на ринку праці; цілісна система професійного навчання і перепідготовки осіб, які залишилися без роботи чи тих, кому загрожує безробіття; програми навчання та перенавчання для підвищення конкурентоспроможності на ринку безробітних; розробка регіональних програм зайнятості населення та цільових програм громадських робіт; розвиток системи соціального забезпечення. Зарубіжний досвід організації громадських робіт дає змогу раціональніше використовувати робочу силу, створювати тимчасову зайнятість безробітного населення як на регіональному рівні, так i під час реалізації проектів загальнодержавного характеру.

1.Баластрик Л.О. Держава як гарант інноваційної зайнятості. Матеріали Міжнародної науково-практичної конференції «Соціально-трудові відносини: теорія та практика», 22-23 вересня 2010 р. Київ, 2010. С. 52-58.

2. Волинський обласний центр зайнятості. [Електронний ресурс] Режим доступу: https://vol.dcz.gov.ua

3.Головне управління статистики у Волинській області. [Електронний pecypc] Режим доступу: http://www.lutsk.ukrstat.gov.ua/

4. Давидова I.O. Інноваційна зайнятість в аспекті iї сутнісних характеристик 2015. № 5. [Електронний ресурс] Режим доступу : http://www.economy.nayka.com.ua/?op=1\&z=4041

5. Руженський М. М. Працевлаштування як форма соціального захисту населення, 2013. № 2. С. 8-11.

6. Туринський процес 2016. Україна. Регіональний рівень. Аналіз системи професійно-технічної освіти Волинської області. Проект Європейського Фонду Освіти «Туринський процес 2016-17» / Київ. «Вік принт». 2016. 99 с. 